\title{
Studies on the mycoflora of maize grain
}

\section{Shila Sakhala}

Department of Botany, Nanasaheb Y. N. Chavan Arts Sciences and Commerce College, Chalisgaon, Jalgaon, Maharashtra State, India.

\section{Received: October 18, 2016; Accepted: November 15, 2016}

\begin{abstract}
Maize is an important food and fodder crop. Its grains are important for the production of starch, oil and glucose. It is an important component of both human and animal diet. During storage grains undergo quantitative and qualitative losses. A large number of pathogenic fungi, bacteria, viruses and insects affecting maize cause combined world annual losses of $9.4 \%$ (Shrutelff, et al., 1980). Fungi affect quality of grain through increase in fatty acid, reduction in germination and finally spoilage of grain. The importance of fungi is also due to production of toxin that cause health hazards in human and animals. In the present study two variety of maize N 2277 and S 2727 which are locally grown crop in our area were collected directly from the field. Mycoflora of maize was tested by using blotter method. Moisture content, percent germination was also studied. A total of 8 fungi were observed from the grain.
\end{abstract}

Key words: mycoflora; maize; fodder

\section{Introduction}

Maize in an inferior grain which is used both as food and fodder. Its grain provides food and is used for obtaining starch and glucose. Its stalk is feed of cattle. It has long been noted that seed born fungal pathogens are responsible for reducing seed quality protein and carbohydrates content, reduction or elimination of germination capacity as well as seedling damage which results in the reduction of crop yield (Mustaq and Hashmi, 2005). Fungi are the second important causes of deterioration and loss of maize next to insect. (Verga and J. Jareen, 2005). In the present study two cultivars of maize N 2277 and S 2727 were explored for moisture content, percentage germination and mycoflora associated with grain.

\section{Materials and Methods}

Maize cultivar N 2277 and S 2727 directly collected from the farmer, recently harvested grain from Kajgaon (Bhadgaon). After bringing samples to laboratory, moisture content was observed on wet weight basis. For the screening of mycoflora blotter test was followed (Neergaard, 1977). A total of 200 grains from each sample were screened after 8 days of incubation and were identified following Ellis (1971).

\section{Result and Discussion}

Maize is a major source of starch. Corn starch (Maize flour) is a major ingredient in a home cooking and in many industrialized food products. Fungi could cause about $50-80 \%$ damage of maize during storage if conditions are favourable for their development. It is clear from the results that both crops having low moisture content but percent germination is higher in S 2727 with the range of radicle length 1.3 to $12 \mathrm{~cm}$ and found only one grain infected with Aspergillus niger. (Fig.1) Maize cultivar with moisture content 0.31 is poor in germination $(88 \%)$ and most of the grain showed presence of mycoflora, such as Aspergillus niger, A. flavus, Fusarium sp., Nigrospora sp., Cladosporium sp. Alternariasp. and Helminthosporium sp. Most of the grains were found infected with Fusarium sp. but in this variety plumule development also found with the range 1.4 to 5.8 plumule germination was observed only on14 grains. Aspergillus niger, A. flavus, Fusarium sp, Nigrospora sp., Cladosporium sp. and Helminthospocium sp., Penicillium sp. and Alterneria sp. (Table 1) were found associated with the grains. A number of fungi observed in the present study are known to produce mycotoxin which are harmful for human health mycotoxinscan cause severe damage to liver, kidney and nervous system of human being even in low dosages (Verga and J. Jareen, 2005). Present study revealed that S 2727 variety is more suitable as compared to N 2277 as this variety harbour negligible mycoflora.

\section{Table:}

\begin{tabular}{lcc}
\hline \multicolumn{1}{c}{ Parameter } & Cultivar N 2277 & Cultivar S 2727 \\
\hline Moisture content & 0.31 & 0.17 \\
\% germination & 88 & 100 \\
Radical length & Range 1 to $12 \mathrm{~cm}$ & 1.0 to $12 \mathrm{~cm}$ \\
Plumule length & Range 1.4 to 6.0 & 00 \\
Mean of radical & 4.12 & 3.54 \\
Mean of plumule & 2.66 & - \\
Date of collection & $27-10-2015$ & $27-10-2015$ \\
\hline
\end{tabular}

\footnotetext{
*Corresponding Author:

Shila Sakhala,

Department of Botany,

Nanasaheb Y. N. Chavan Arts Sciences and Commerce College,

Chalisgaon, Jalgaon, Maharashtra State, India.

E-mail: shailasakhala19@yahoo.co.in
}

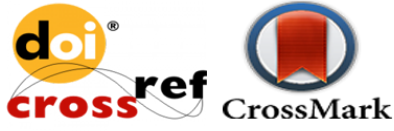




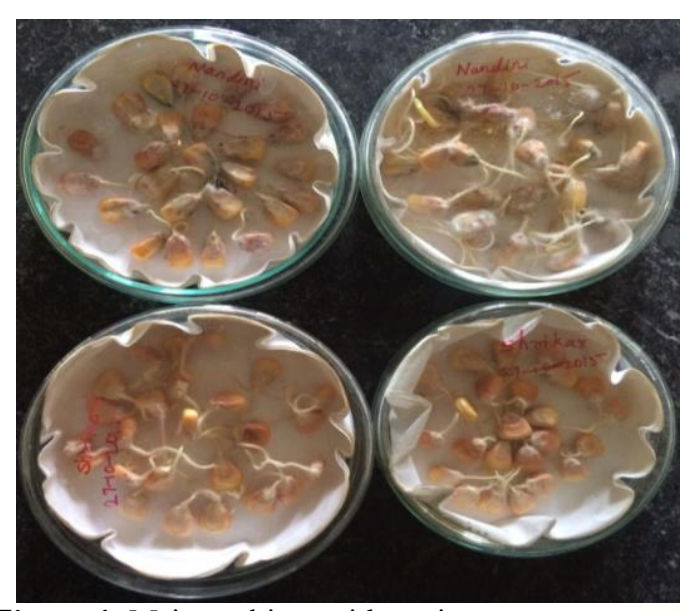

Figure 1: Maize cultivar with moisture content

\section{References}

1. Ellis, M.B. (1971). Demotiaceous Hyphomycetes. C.M.I., Kew Surrey England, 608 pp

2. Mustaq SNM, Hashmi M. H. (2005) seed borne mycoflora of sunflower (Helianthus annuus L.) Pak. J. Bot. 37(2): 451-457

3. Neeergaard 1977 P. seed Technology. The Macmillan Press Ltd. London.

4. Shurtleff, M.C. (1980). Compendium of corn diseases. American Phytopathological Society. St. Paul Minnesota, 105 pp.

5. Verga, B. Toth and J. Teren. 2005. Mycotoxin producing fungi and mycotoxins in foods in Hungary. Journal of Acta Alimentaria/Akademiai, 267-275.

\section{Cite this article as:}

Shila Sakhala. Studies on the mycoflora of maize grain, Annals of Plant Sciences 5.11 (2016): 1454-1455.

DOI: http://dx.doi.org/10.21746/aps.2016.11.002

Source of support: Nil.

Conflict of interest: None Declared 